\title{
МОЛОДЕЖЬ И БЕЗРАБОТИЦА: СИТУАЦИЯ В МИРЕ
}

\author{
И. В. Вирина \\ (Московский гуманитарный университет)
}

Аннотация: В статье рассмотрены проблемы занятости и безработицы молодежи. Выявлены и обоснованы глобальные тенденции безработицы молодежи. Проанализированы актуальные показатели безработицы, показаны меры по решению проблемы трудоустройства и обеспечения конкурентоспособности молодежи.

Ключевые слова: молодежь; безработица; конкурентоспособность; инклюзивность рынка труда

\section{THE THEME OF GENEROSITY IN EARLY ENCOMIA TO GRAND PRINCE VLADIMIR SVIATOSLAVICH OF KIEV}

\author{
I. V. Virina \\ (Moscow University for the Humanities)
}

Abstract: The article deals with the issues of youth employment and unemployment, identifying the global trends in the latter. We analyze the current joblessness indicators and outline the steps towards reducing youth unemployment and ensuring their competitiveness. market

Keywords: youth; unemployment; competitiveness; inclusivity of the labor

Молодежь - это такая социально-демографическая группа общества, которая характеризуется в первую очередь тем, что находится на стадии трудового и социального самоопределения, еще не сформировалась как субъект трудовой деятельности, имеет способность к постоянной смене трудовых функций. В силу этого она является достаточно ярко выраженной группой риска, и поэтому этого обладает рядом специфических признаков, отличающих ее от других социально-возрастных групп: 1) выходит на рынок труда впервые и отличается от взрослых работников отсутствием значительного производственного стажа; 2) отличается неустойчивостью жизненных установок, и из-за этого более мобильна при выборе и поиске рабочего места; 3) имеет более низкий статус занятости; 4) характеризуется зачастую низким уровнем профессиональной ориентации, информиро- 
ванности о состоянии рынка труда, спросе на конкретные специальности, возможностях профессионального обучения, об основах трудового законодательства; 5) имеет свои специфические притязания к режиму работы, уровню оплаты труда и карьерному росту (Вирина, Якимов, 2008: 35). Научный интерес вызывают проблемы безработицы, конкурентоспособности молодого специалиста на рынке труда. Цель настоящей статьи - рассмотрение глобальных тенденций в области занятости и безработицы молодежи в мировом пространстве.

После стремительного роста в период с 2007 по 2010 гг. уровень молодежной безработицы стабилизировался на отметке 13\%, однако этот показатель значительно превышает докризисный уровень (11,7\%), говорится в опубликованном докладе Международной организации труда (MOT) «Глобальные тенденции занятости молодежи 2015» (Youth employment ..., 2015: Электр. ресурс). В докладе подчеркивается сокращение числа безработных молодых людей до 73,3 млн человек в 2014 г. Это на 3,3 млн меньше, чем в разгар кризиса - 76,6 млн человек в 2009 г. По сравнению с 2012 г. уровень молодежной безработицы снизился на $1,4 \%$ в развитых экономиках и странах Европейского союза и на 0,5\% и менее в странах Центральной и ЮгоВосточной Европы (не входящих в ЕС) и СНГ, странах Латинской Америки и Карибского бассейна и странах Африки к югу от Сахары. В остальных регионах - странах Восточной Азии, Юго-Восточной Азии и Тихоокеанского региона, Ближнего Востока и Северной Африки - в период с 2012 по 2014гг. отмечен рост молодежной безработицы или отсутствие изменений, как в странах Южной Азии.

Однако нельзя упускать и тот факт, что восстановление занятости молодежи не носит всеобщего характера, и что почти 43\% молодой рабочей силы в мире все еще остаются безработными или, работая, все равно живут в бедности. Большее число молодых людей в развитых странах находит работу, но качество этих рабочих мест не соответствует их ожиданиям. Доля молодежи, трудоустроенной или безработной, в общей численности рабочей силы в мире с течением времени снижается. Одна из причин состоит в том, что все больше молодых людей получают образование (хотя их число все еще недостаточно). Однако миллионы молодых людей в странах с низкими доходами по-прежнему слишком рано оставляют школу, чтобы пойти работать. Результаты недавних исследований показывают увеличение числа молодежи, вступающих на рынок труда сразу после школы (school-towork transition surveys - SWTS). Молодой специалист, окончивший университет, в три раза быстрее находит стабильную работу, чем тот, кто получил только начальное образование. По данным доклада МОТ, 31\% молодежи в странах с низкими доходами вообще не имеет какого-либо законченного образования, по сравнению с $6 \%$ в странах с средними доходами и $2 \%$ в 
странах с доходами выше среднего. Кроме того, сохраняется гендерное неравенство на рынке труда: в большинстве регионов молодых женщин на рынке труда значительно меньше, чем мужчин. Они по-прежнему более подвержены риску безработицы, чем мужчины (там же).

По-прежнему слишком многие остаются длительно безработными: в странах Европейского союза каждый третий молодой человек ищет работу больше года. Со второго квартала 2008 г. уровень безработицы среди молодежи вырос до 23,9\% в первом квартале 2013 г., а затем снизился до 19,7\% в конце 2015 г. В целом в Евросоюзе, уровень безработицы среди молодежи был систематически выше, чем в период с 2000 до середины 2007 г. (Eurostat Statistics Explained ..., Электр. ресурс).

Следует заметить, что уровень молодежной безработицы в Европейских странах измеряется как процент безработных в возрастной группе от 15 до 24 лет по сравнению с общей численности рабочей силы (как занятые и безработные) в этой возрастной группе. При этом значительная доля людей в этом возрасте находятся за пределами рынка труда (так как многие молодые люди учатся полный день и, следовательно, не могут трудиться вообще, что объясняет, почему уровень безработицы среди молодежи, как правило, выше, чем общие показатели безработицы у других возрастных групп.

При этом на развивающиеся страны продолжают влиять проблемы структурной неполной занятости, неформальной занятости и «работающих бедных». Борьба с молодежной безработицей, порождающей социальную незащищенность и ощущение отверженности, могла бы внести значительный вклад в развитие мировой экономики. По расчетам МОТ, сокращение вдвое уровня безработицы среди молодежи обеспечило бы прирост мирового ВВП по меньшей мере на 2,2 трлн. долл., что равняется $4 \%$ мирового ВВП в 2003 г. Более того, те, кто успешно начал трудовую жизнь, имеют меньший риск длительной безработицы в будущем (Гневашева ..., Электр. ресурс).

Кроме того, «слишком высокая безработица среди молодежи является одной из основных причин для быстрой потери доверия и серьезную угрозу для социальной демократии и сплоченности», отмечает Райнер Хоффман председатель Германской федерации профсоюзов (DGB) (Hoffmann, 2016: Электр. ресурс). По его мнению, необходимо межстрановое сотрудничество в области содействия занятости, обеспечение возможности участия молодежи в некоммерческих социальных и экологических проектов в разных европейских странах. Это не приведет к решению проблемы безработицы среди молодежи, но способствует терпимости, единения и межкультурной компетентности. Настоящая борьба с безработицей в целом - это целый набор исправлений политики, которая выходит далеко за рамки программ рынка труда: согласование корпоративного налогообложения и эффектив- 
ной борьбы с уклонением от уплаты налогов; регулирование рынков капитала; усиление социальных прав специалистов.

В России проблема трудоустройства молодежи, как и в других странах, стоит довольно остро. Средний возраст безработных в декабре 2015 г. составил 35,8 года. Молодежь до 25 лет среди безработных составляет 23,8\%, в том числе в возрасте 15-19 лет - 4,7\%, 20-24 лет - 19,1\%. Высокий уровень безработицы отмечался в возрастной группе $15-19$ лет $(35,4 \%)$ и $20-24$ лет (14,1\%). В среднем среди молодежи в возрасте 15-24 лет уровень безработицы в декабре 2015 г. составил 16,0\%, в том числе среди городского населения $-14,5 \%$, среди сельского населения - 19,9\%. Коэффициент превышения уровня безработицы среди молодежи в среднем по возрастной группе 15-24 лет по сравнению с уровнем безработицы населения в возрасте 3049 лет составляет 3,3 раза, в том числе среди городского населения $-3,5$ раза, сельского населения - 2,7 раза (Занятость и безработица ..., Электр. ресурс). В связи с безработицей и сложностью трудоустройства снижается и жизненный уровень. Ухудшение материального положения сопровождается расслоением по уровню жизни большинства молодежи. Особенно это касается выпускников высших и средних специальных заведений. Многие из них подолгу не могут найти работу, и вынуждены искать неофициальные формы занятости. Доля безработных, ищущих работу один год и более, составляет 28,6\%. Под влияниемэтого фактора, чтобы поддерживать определенный уровень жизни, многие предприимчивые молодые люди выбирают антисоциальные сферы занятости, особенно это распространено среди несовершеннолетних (Ромашова, 2015: Электр. ресурс).

Анализ мировых тенденций в области молодежной безработицы показывает, что стремительное развитие технологий, изменения в организации труда и трудовых отношениях, а также новые формы предпринимательства требуют постоянно адаптироваться к новым условиям рынка труда и приводить профессиональные навыки в соответствие с потребностями рынка труда. Чтобы обеспечить молодежи лучшие возможности, конкурентоспособные позиции для перехода к достойному трудоустройству, нужно:

- инвестировать в образование и обучение максимально высокого качества, дающие молодым людям навыки, которые отвечают требованиям рынка труда;

- обеспечивать им доступ к социальной защите и основным услугам, какой бы ни был их трудовой договор, и создавать равные условия для всех, чтобы каждый целеустремленный молодой человек, независимо от пола, уровня доходов и социально-экономического положения, мог продуктивно трудиться;

- увеличивать объем инвестиций в производство и повышать инклюзивность рынков труда и общества в целом. 


\section{СПИСОК ЛИТЕРАТУРЫ}

Вирина, И., Якимов, В., (2008) Формирование и развитие конкурентоспособности молодых специалистов. М. : Изд-во Моск. гуманит. ун-та. 144 с.

Гневашева, В. А. (2007) Особенности молодежного рынка труда в России [Электронный ресурс] // Информационный гуманитарный портал «Знание. Понимание. Умение». URL: http://www.zpu-journal.ru/gum/new/ articles/2007/Gnevasheva/ (дата обращения: 10.10.2016).

Занятость и безработица в Российской Федерации в декабре 2015 года (по итогам обследования населения по проблемам занятости) [Электронный ресурс] // Федеральная Службы государственной статистики. URL: http://www.gks.ru/bgd/free/B04_03/IssWWW.exe/Stg/d06/16.htm (дата обращения: 13.10.2016).

Ромашова, Л. О. (2015) Современное состояние рынка труда молодежи в России [Электронный ресурс] // Научные труды Московского гуманитарного университета. № 4. URL: http://journals.mosgu.ru/trudy/article/view/48 (дата обращения: 10.09.2016). DOI: 10.17805/trudy.2015.4.4

Eurostat Statistics Explained (2016) [Электронный ресурс]//Eurostat.URL: http://ec.europa.eu/eurostat/statistics-explained/index.php/Unemployment_ statistics\#Youth_unemployment_trends (дата обращения 10.10.2016).

Youth employment crisis easing but far from over (2015) [Электронный ресурс] // Информационный портал Международной Организации труда. 7 октября. URL:http://www.ilo.org/global/about-the-ilo/newsroom/news/ WCMS_412014/lang--en/index.htm (дата обращения 12.10.2016).

Hoffmann, R. (2016) Die EU muss weltoffener, solidarischer, sozialer werden [Электронный ресурс] // Информационный журнал Шпигель. 7 июля. URL:http://www.spiegel.de/wirtschaft/soziales/brexit-folge-die-eu-mussweltoffener-solidarischer-sozialer-werden-a-1101698.html (дата обращения 12.10.2016).

Вирина Ирина Владимировна - кандидат экономических наук, доцент кафедры социологии Московского гуманитарного университета. Адрес: 111395, Россия, г. Москва, ул. Юности, д. 5. Тел.: +7 (499) 374-60-21. Эл. адрес: virina_iv@rambler.ru

Virina Irina Vladimirovna, Candidate of Economics, Associate Professor, Department of Sociology, Moscow University for the Humanities. Postal address: 5 Yunosti St., 111395, Moscow, Russian Federation.Tel.: +7 (499) 374-60-21. E-mail: virina_iv@rambler.ru 